\title{
Expanding our understanding of leaf functional syndromes in savanna systems: the role of plant growth form
}

\author{
Davi Rodrigo Rossatto ${ }^{1}$ Augusto Cesar Franco ${ }^{2}$
}

Received: 27 July 2016 / Accepted: 9 January 2017 / Published online: 25 January 2017

(C) Springer-Verlag Berlin Heidelberg 2017

\begin{abstract}
The assessment of leaf strategies has been a common theme in ecology, especially where multiple sources of environmental constraints (fire, seasonal drought, nutrientpoor soils) impose a strong selection pressure towards leaf functional diversity, leading to inevitable tradeoffs among leaf traits, and ultimately to niche segregation among coexisting species. As diversification on leaf functional strategies is dependent on integration at whole plant level, we hypothesized that regardless of phylogenetic relatedness, leaf trait functional syndromes in a multivariate space would be associated with the type of growth form. We measured traits related to leaf gas exchange, structure and nutrient status in 57 coexisting species encompassing all Angiosperms major clades, in a wide array of plant morphologies (trees, shrubs, sub-shrubs, herbs, grasses and palms) in a savanna of Central Brazil. Growth forms differed in mean values for the studied functional leaf traits. We extracted 4 groups of functional typologies: grasses (elevated leaf dark respiration, light-saturated photosynthesis on a leaf mass and area basis, lower values of leaf $\mathrm{Ca}$
\end{abstract}

Communicated by Fernando Valladares.

Electronic supplementary material The online version of this article (doi:10.1007/s00442-017-3815-6) contains supplementary material, which is available to authorized users.

Davi Rodrigo Rossatto

drrossatto@gmail.com

1 Departamento de Biologia, Faculdade de Ciências Agrárias e Veterinárias, Universidade Estadual Paulista (UNESP), Via de Acesso Prof. Paulo Donatto Castellane S/N, Jaboticabal, SP 14884-900, Brazil

2 Departamento de Botânica, Instituto de Ciências Biológicas, Universidade de Brasília, Caixa Postal 04457, Brasília, DF 70919-970, Brazil and $\mathrm{Mg}$ ), herbs (high values of SLA, leaf $\mathrm{N}$ and leaf Fe), palms (high values of stomatal conductance, leaf transpiration and leaf $\mathrm{K}$ ) and woody eudicots (sub-shrubs, shrubs and trees; low SLA and high leaf $\mathrm{Ca}$ and $\mathrm{Mg}$ ). Despite the large range of variation among species for each individual trait and the independent evolutionary trajectory of individual species, growth forms were strongly associated with particular leaf trait combinations, suggesting clear evolutionary constraints on leaf function for morphologically similar species in savanna ecosystems.

Keywords Cerrado · Ecophysiology $\cdot$ Niche separation Palm · Traits

\section{Introduction}

In accordance with the niche theory, habitat filtering and phylogeny act in concert to shape which functional strategies can be successful in a particular environment (Webb et al. 2002; Fukami et al. 2005; Grime 2006). Temporal and spatial variability in abiotic filters may promote significant functional diversification (Lortie et al. 2004; Grime 2006; Cavender-Bares et al. 2004; Ackerly 2009), particularly in water-stressed and disturbance-prone environments such as savannas where fire is pervasive. Functional diversification often occurs along multiple axes of ecological differentiation (Grime 2002; Garnier and Navas 2012; Sandel et al. 2016), and those associated with resource capture, allocation, and stress tolerance are often related to leaf structural or chemical traits and to traits regulating leaf $\mathrm{CO}_{2}$ exchange and water loss (Westoby et al. 2002; Wright et al. 2005). Diversification on leaf functional strategies is dependent on integration at whole plant level and, as such, underpinned by the overall growth form of the plant. As a 
result of developmental and mechanical constraints, any individual growth form is not expected to fill a considerable part of the multivariate trait space and may be restricted to particular sets of trait value combinations within the multivariate trait space (Diaz et al. 2004, 2016; Santiago and Wright 2007). Segregation of growth forms along continuous axis of variation is likely to occur at local scale driven by local environmental conditions and biological interactions (Lavorel and Garnier 2002). Studies that attempt to integrate trait syndromes and growth forms better reflect the coordinated evolution of structure and function of the whole plant (Rowe and Speck 2005) and, furthermore, can reveal evolutionary constraints on plant function and foster our understanding of mechanisms of species coexistence.

Neotropical savannas are well suited for this type of study because a large number of growth forms with different evolutionary trajectories (trees, shrubs, sub-shrubs, herbs, grasses and palms) share dominance (Gottsberger and Silberbauer-Gottsberger 2006; Mendonça et al. 2008). Grasses and palms represent narrow taxonomic groupings, whereas savanna trees and shrubs are the product of convergent evolution of a large number of phylogenetically distant groups (Maurin et al. 2014). Most herbaceous eudicots are probably from lineages that have a long evolutionary history within open habitats (Simon et al. 2011). Sub-shrubs may be on an evolutionary trajectory that converges ecologically with herbaceous plants, but they might also share many traits with the tree lineages from which they evolved. In this context, studies that consider all major growth forms present in a plant community and having species distributed throughout the major angiosperm lineages (controlling for the phylogenetic influence) can provide a better understanding of ecophysiological strategies, which generally involve not only single traits, but also complex suites of interrelated traits shaped by natural selection. This information is also essential to develop more realistic scenarios of future shifts in the composition and structure of savanna plant communities in response to global warming (Franco et al. 2014).

This type of approach is particularly relevant for studies on the Cerrado vegetation, a complex mosaic of fire-prone savanna physiognomies covering about 2 million $\mathrm{km}^{2}$ of the Brazilian territory (Oliveira-Filho and Ratter 2002) and that supports a rich assemblage of plant species with high levels of phylogenetic diversity (Rossatto 2014). The long dry season spanning from May to September, when rains are not frequent, imposes significant constraints on plant water balance and carbon assimilation (Franco 2002; Goldstein et al. 2008). Additionally, aspects linked with nutrientpoor acid soils with elevated Al concentration (Haridasan 2000, 2008) and fire as an important source of disturbance (Hoffmann et al. 2012; Franco et al. 2014), may be selecting for a set of specific adaptations. Such combination of multiple sources of stress, disturbance and of plant communities with diversified growth forms makes the Cerrado a unique system to test whether different growth forms are associated with distinct strategies to acquire and allocate carbon and nutrients to sustain metabolic processes, growth and reproduction.

Here, we focused on the segregation of functional leaf trait values among growth forms. We chose traits related to leaf gas exchange, leaf structure and nutritional status, which were measured in 57 cerrado species, differing in shoot morphology and belonging to distinct families in the angiosperm phylogeny (APG IV 2016). All individuals were growing side by side in savanna conditions. We test the hypothesis that each growth form would be associated with particular combinations of multiple-correlated leaf traits in a multivariate trait space. Specifically, we hypothesized that because of their small size, cerrado herbs would show leaf traits linked with rapid growth and faster life cycles, namely leaves with higher photosynthetic rates, higher specific leaf area and leaf nutrient content, since they need to quickly grow and reproduce after the fire passage in savanna environments before being overtopped by regrowth of the surrounding vegetation (Hoffmann 1996). Because the photosynthetic $\mathrm{C}_{4}$ pathway is prevalent in tropical savanna grasses (Edwards and Smith 2010; Liu et al. 2012), grasses and herbs were expected to have different nutrient requirements and should segregate in the multivariate trait space. In contrast, because of the larger size, selection pressures on woody species would favor leaf trait syndromes that contribute more strongly to long-term growth and survival than to rapid growth or high fecundity. We hypothesized that typical woody growth forms (trees and shrubs) would have leaves selected for lower photosynthetic rates, lower specific leaf area and lower leaf nutrient concentrations. Because of their unique morphology and the strong phylogenetically conservatism in their traits (Roncal et al. 2012), palms would not share the same trait syndromes of woody plants, while sub-shrubs would fill the intermediate region between herbs and woodier species in the multivariate trait space.

\section{Materials and methods}

\section{Study area}

This study was carried out at Ecological Reserve of IBGE (Instituto Brasileiro de Geografia e Estatística) in the surroundings of the city of Brasília in the Federal District, Brazil, located at $15^{\circ} 56^{\prime} 41^{\prime \prime} \mathrm{S}$ and $47^{\circ} 53^{\prime} 07^{\prime \prime} \mathrm{W}$ and at an elevation of approximately $1100 \mathrm{~m}$ above sea level. In the year of the study, total rainfall was $1492 \mathrm{~mm}$ and the average temperature was $22.10{ }^{\circ} \mathrm{C}$. During the dry season 
(May-September), the total rainfall was $137.6 \mathrm{~mm}$ (less than $50 \mathrm{~mm}$ in each month) and average temperature was $21.45{ }^{\circ} \mathrm{C}$.

\section{Studied species and growth form classification}

We selected 57 species from different families, which were growing in five $20 \mathrm{~m} \times 50 \mathrm{~m}$ plots located at an extended and continuous typical savanna area (regionally called cerrado sensu stricto, a vegetation type associated with the savanna biome of Brazil). This area has not burned for the previous 20 years (latest fire occurred on 1996), and had a tree basal area of $9.2 \pm 1.2 \mathrm{~m}^{2} \mathrm{ha}^{-1}$ (Rossatto et al. 2012). Species were distributed throughout the major clades of angiosperms (to control for phylogenetic influence) and also belonged to different growth forms (see Fig. 1) and were thriving on similar soil conditions (Table S1). The species enclosed a wide array of woody and herbaceous growth forms, comprising trees, shrubs, sub-shrubs, herbs, grasses and palms (Fig. S1). Nonetheless, each of the highest clades (or nodes) of the angiosperm phylogeny (i.e., Magnoliids, Commelinids, Fabids, Malvids, Campanulids and Lamiids) was represented by at least one tree, one shrub, one sub-shrub, and one herb with the exception of Magnoliids and Commelinids clades (Fig. 1). We sampled 10 species of trees, 10 species of shrubs, 11 species of sub-shrubs, 11 species of herbs, 10 species of grasses and 5 species of palms. The selected species represent the most common and dominant species in the studied area. We followed the classification system proposed by Dansereau (1951), which relies on the form (morphological aspects and height) that plants can achieve in their aboveground structure. Based on this classification and field observations, we adopted the following growth form definitions:

- Tree: Woody plant with a defined stem, generally taller than $2 \mathrm{~m}$ and with highly suberized trunk and shoots.

- Shrub: Woody plant with 2-3 m of height without a predominant stem, being ramified near the stem base, also possessing thickened branches and stems.

- Sub-shrub: A semi-woody plant of around 0.5-1 m in height, ramified, generally with a thickened, partially lignified stem, but with herbaceous branches and dying back near to the ground at each dry season.

- Herb: A small eudicot plant around $10-30 \mathrm{~cm}$ in height, with herbaceous stems and branches.

- Palms: here defined as a species of the Arecaceae family, generally having an unbranched stem with a terminal crown of evergreen palmate or pinnate leaves.

- Grasses: here defined as a species of the Poaceae family; plants with herbaceous stems in the form of culms and slender sheathing leaves.

\section{Leaf functional trait measurements}

We measured functional leaf traits related to leaf gas exchange and leaf nutrient status during the wet season, in February 2009. The wet season is the time of the year when these traits are at their maximum, given the high availability of resources such as light, water and nutrients (Franco et al. 2005; Rossatto et al. 2013a). Maximum $\mathrm{CO}_{2}$ assimilation $\left(A_{\text {area }}\right)$, transpiration $(E)$ and stomatal conductance ( $g_{\mathrm{s}}$, the degree of stomatal opening) on a leaf area basis were determined under ambient $\mathrm{CO}_{2}$ (399-410 ppm) with a portable open photosynthesis system (LCpro, Analytical Development Co., Hoddesdon, UK). The system was coupled with a led light source providing a light intensity between 1300 and $1400 \mu \mathrm{mol} \mathrm{m} \mathrm{m}^{-2} \mathrm{~s}^{-1}$, proved enough to saturate the photosynthetic apparatus of most savanna species (Franco et al. 2005). However, as most of the studied grasses were $\mathrm{C}_{4}$ (Table S2) we used a light intensity of $2000 \mu \mathrm{mol} \mathrm{m} \mathrm{m}^{-2} \mathrm{~s}^{-1}$ for grasses. Leaf respiration $\left(D_{\text {resp }}\right)$ was also measured by submitting the leaves to total darkness for a period of about $5 \mathrm{~min}$. Leaf temperature was maintained around $26 \pm 1.5{ }^{\circ} \mathrm{C}$ in all cases. All measurements were carried on one sunlit leaf of five pre-marked individuals of each species during a 2- to 4-h period between 08:00 and 12:00 h. We calculated $\mathrm{CO}_{2}$ assimilation on a mass basis $\left(A_{\text {mass }}\right)$, as the product of specific leaf area $\left(\mathrm{SLA} ; \mathrm{cm}^{2} \mathrm{~g}^{-1}\right)$ and $A_{\text {area }}\left(\mu \mathrm{mol} \mathrm{m} \mathrm{m}^{-2} \mathrm{~s}^{-1}\right)$ and intrinsic water use efficiency (IWUE) as the ratio of $A_{\text {area }}$ to $g_{s}$. After gas exchange measurements, each leaf was collected and scanned on a flatbed scanner and its area was determined using the free software Image J. The leaf was then dried at $70{ }^{\circ} \mathrm{C}$ for three days and weighed for the determination of SLA. The dried leaves used for SLA were finely ground and a subsample was taken for total $\mathrm{N}, \mathrm{P}, \mathrm{K}, \mathrm{Ca}$, $\mathrm{Mg}$ and $\mathrm{Fe}$ determinations. $\mathrm{N}$ was determined in diluted acid digests according to the micro-Kjeldahl procedure (Allen et al. 1974). Total extractable $\mathrm{P}$ was determined colorimetrically by complex formation with molybdovanadate according to Allen et al. (1974). Other elements were determined by flame spectrophotometry.

\section{Data analysis}

We used one-way ANOVA followed by Tukey's HSD test $(\alpha=0.05)$ to compare individual leaf traits among the growth forms. Prior to the analysis, we checked for data normality and homoscedasticity. Transformation using $\log _{10}$ was used when necessary. We used principal components analysis (PCA) to verify if species that shared the same type of growth form also had a similar syndrome of functional leaf traits. All data were standardized (z-transformation) before applying the analysis. For the PCA, we used the Euclidian distance with the 
Fig. 1 Phylogenetic relationships of the 57 studied species. Name of the species is followed by types of growth form. Names at intermediate positions indicate presumably monophyletic groups according to APG IV (2016)

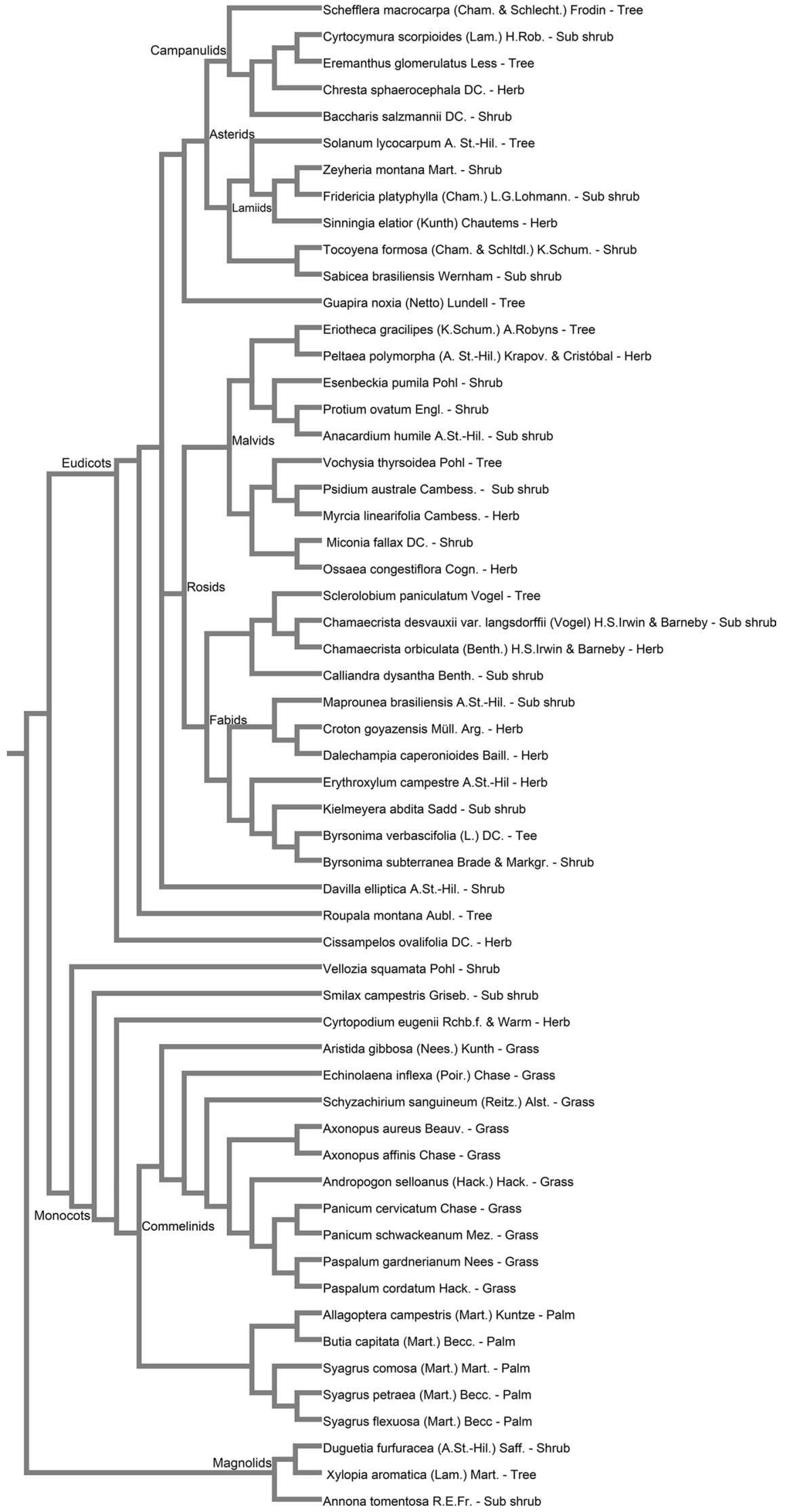


Fig. 2 Variation among growth forms in gas exchange traits and specific leaf area. a $A_{\text {area }}$ : maximum $\mathrm{CO}_{2}$ assimilation on a leaf area basis; $\mathbf{b} g_{\mathrm{s}}$ : stomatal conductance at $A_{\text {area }}$; c $D_{\text {resp: }}$ : leaf respiration under dark conditions; d SLA: specific leaf area; e $A_{\text {mass }}$ : maximum $\mathrm{CO}_{2}$ assimilation on a leaf mass basis and $\mathbf{f}$ IWUE: intrinsic water use efficiency. Vertical bars indicate standard error $(n=5$ for palms, $n=11$ for herbs and sub-shrubs and $n=10$ for the other growth forms). Means denoted by the same letter are not significantly different according to Tukey's HSD test $(P<0.05)$
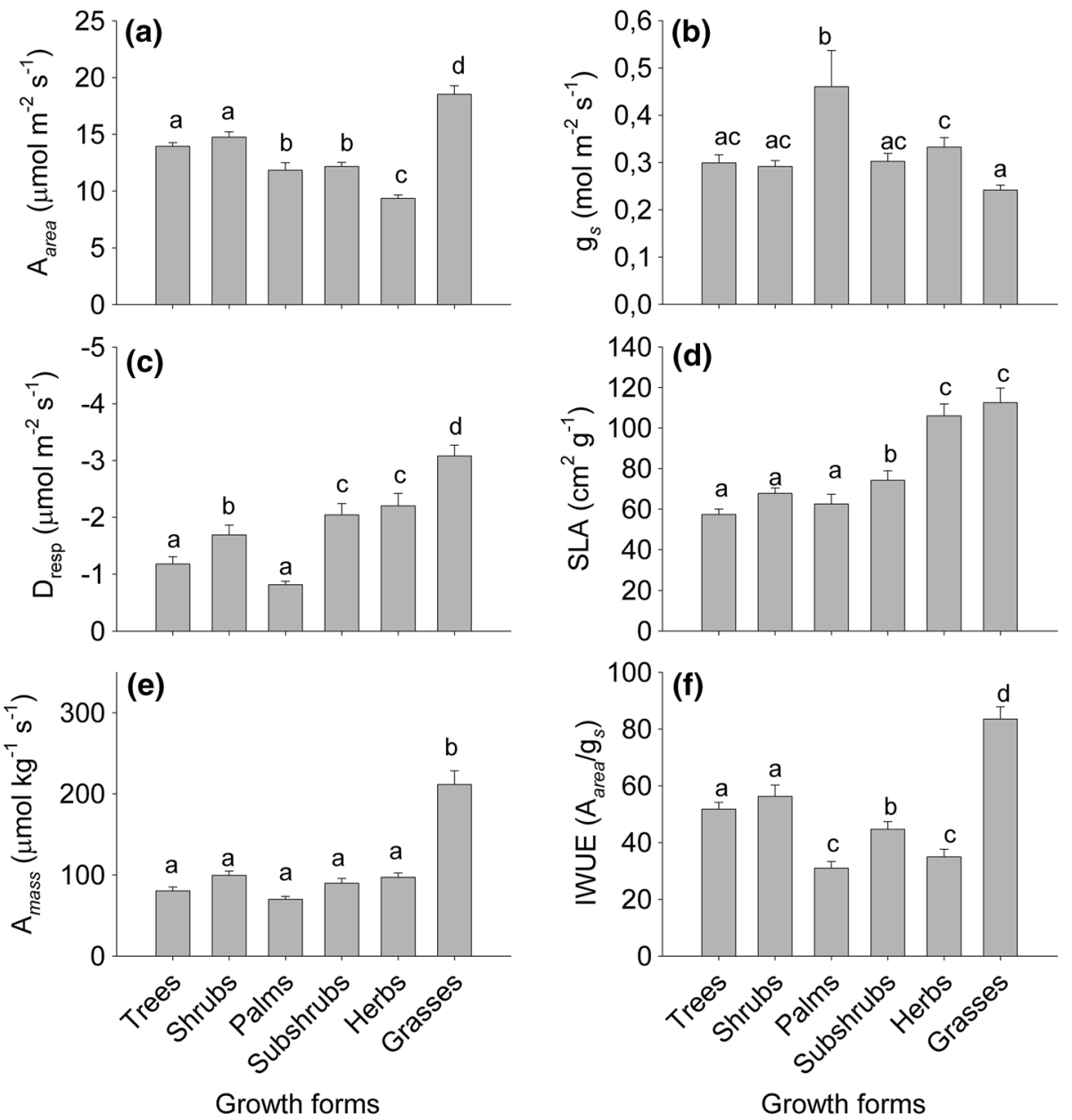

variance-covariance matrix method (Gotelli and Ellison 2004). Only the two most significant axes are shown. The PCA was performed using the free software PAST $2.17 \mathrm{~b}$ (Hammer et al. 2001).

\section{Results}

\section{Leaf trait variation among growth forms}

We observed significant difference $\left(F_{5,51}>10, P<0.01\right)$ among growth forms in all studied gas exchange traits (Fig. 2). Grasses stood as an out-group, being the growth form with the highest $A_{\text {area }}, A_{\text {mass }}$ and SLA (Fig. 2a, d, e). Although the other five growth forms differed in $A_{\text {area }}$ and SLA, they converged to similar values of photosynthesis on a mass basis (around $100 \mu \mathrm{mol} \mathrm{kg} \mathrm{kg}^{-1} \mathrm{~s}^{-1}$, Fig. 2e), which suggests that any differences in $A_{\text {area }}$ among these growth forms were compensated by changes in SLA in the opposite direction: herbs and sub-shrubs had lower values of $A_{\text {area }}$ but higher values of SLA than trees and shrubs. Because grasses had the lowest values of $g_{s}$, they also had the highest values of IWUE (Fig. 2f). On the other hand, palms and herbs had the lowest values of IWUE. This was the result of the highest values of $g_{\mathrm{s}}$ among growth forms in palms and of the lowest values of $A_{\text {area }}$ among growth forms in herbs (Fig. 2a, b). There was a tendency for herbaceous growth forms to present higher rates of $D_{\text {resp }}$, in particular grasses had rates of $D_{\text {resp }}$ that were significantly higher than those of the other growth forms (Fig. 2c).

With respect to leaf nutrient traits, we found a significant difference between growth forms $\left(F_{5,51}>12\right.$, $P<0.01$ ), where grasses also stood out. They had the lowest leaf concentrations of $\mathrm{N}, \mathrm{P}, \mathrm{Ca}, \mathrm{Mg}$ and $\mathrm{K}$ but the highest leaf concentrations of $\mathrm{Fe}$ (Fig. 3). In particular, their leaf $\mathrm{N}$ and $\mathrm{P}$ concentrations were very low in comparison to the other growth forms. Palms shared similar low values of leaf $\mathrm{Ca}$ and $\mathrm{Mg}$ with grasses (Fig. 3c, d). On the other hand, they had the highest leaf concentrations of $\mathrm{P}$ and $\mathrm{K}$ among growth forms (Fig. 3b, e). Trees had the highest leaf concentrations of $\mathrm{Ca}$ (Fig. 3c) and $\mathrm{Mg}$ (Fig. 3d) and, after grasses, the lowest leaf concentrations of $\mathrm{N}$ (Fig. 3a) and $\mathrm{P}$ (Fig. 3b). Shrubs, sub-shrubs and herbs shared similar values of leaf N, P and Mg (Fig. 3a, b, d). Herbs differed from 
Fig. 3 Variation among growth forms in leaf nutrient concentrations. a N: leaf nitrogen concentration; b P: leaf phosphorous concentration; $\mathbf{c} \mathrm{Ca}$ : leaf calcium concentration; $\mathbf{d} \mathrm{Mg}$ : leaf magnesium concentration; $\mathbf{e}$ $\mathrm{K}$ : leaf potassium concentration and $\mathbf{f}$ Fe: leaf iron concentration. Vertical bars indicate standard error ( $n=5$ for palms, $n=11$ for herbs and sub-shrubs and $n=10$ for the other growth forms). Means denoted by the same letter are not significantly different according to Tukey's HSD test $(P<0.05)$
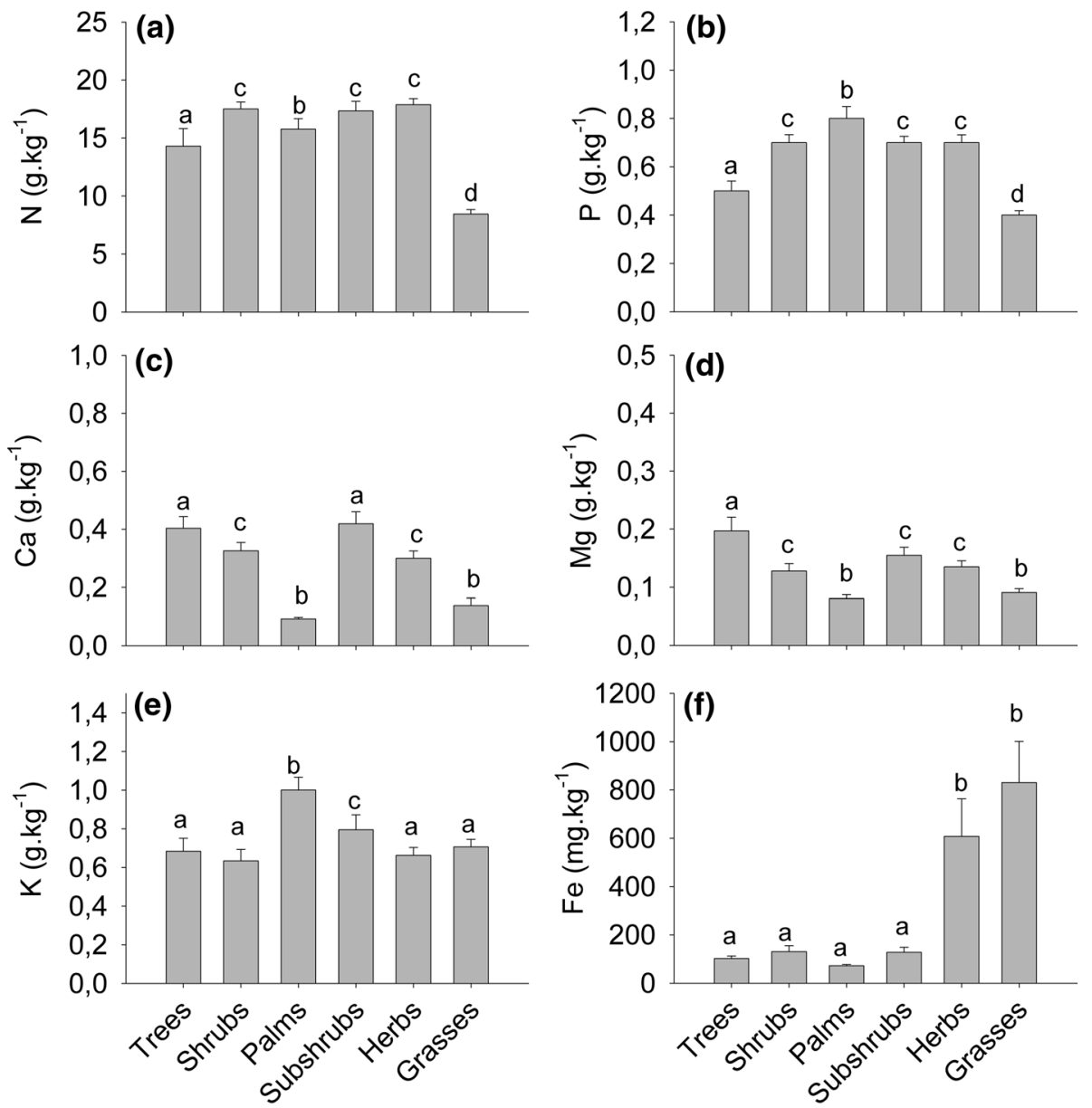

Growth forms

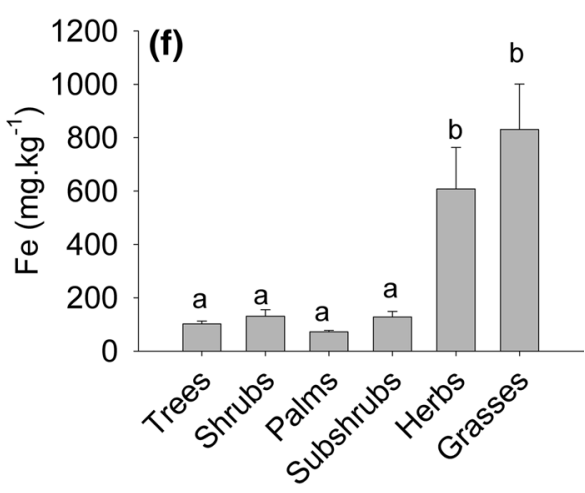

Growth forms shrubs and sub-shrubs by the very high leaf concentrations of Fe (similar to grasses; Fig. 3f) while sub-shrubs differed from herbs and shrubs by the higher leaf concentrations of $\mathrm{Ca}$ and $\mathrm{K}$ (Fig. 3c, e).

\section{Functional trait typologies}

The first and second axes of the PCA explained, respectively, 56.33 and $27.08 \%$ of the variation in the 13 analyzed leaf traits (Fig. 4). The first axis was defined primarily by leaf traits linked with gas exchange and leaf productivity ( $A_{\text {mass }}, \mathrm{SLA}, D_{\text {resp }}$ and $A_{\text {area }}$ ) and two nutrients (P and $\mathrm{Fe}$ ) (Table S3). Traits forming the first axis increased from the right to the left and the herbaceous species and grasses appeared on the left side of the axis, whereas the sub-shrubs, shrubs, palms and trees appeared on the right side of the axis (Fig. 4). Along the second axis, the positioning of growth forms was attributed to leaf $\mathrm{Ca}$, leaf $\mathrm{Mg}$ and E (Fig. 4; Table S3) with monocotyledons appearing on the upper part of the graph (palms and grasses). Considering the two axes, it was possible to define 4 groups of functional typologies: grasses (with high $A_{\text {mass }}$, SLA, $D_{\text {resp }}$ and $A_{\text {area }}$ and low $\mathrm{Ca}$ and $\mathrm{Mg}$ ), herbs (high SLA, P, Ca and $\mathrm{Mg}$ ), palms (high $g_{\mathrm{s}}, \mathrm{E}$ and $\mathrm{K}$ ) and woody eudicots (subshrubs, shrubs and trees; low SLA and higher $\mathrm{Ca}$ and $\mathrm{Mg}$ ).

\section{Discussion}

In agreement with our hypothesis, growth forms in this savanna ecosystem show distinct trait syndromes related to leaf gas exchange, leaf structure and leaf nutrient balance. We, therefore, argue that the growth forms are functionally different, occupying different regions of multivariate functional trait space (as showed by the PCA), thus differing in the way they use and conserve major resources $\left(\mathrm{CO}_{2}\right.$, $\mathrm{H}_{2} \mathrm{O}$ and mineral nutrients) in species-rich savanna ecosystems. The segregation of non-woody and woody plants has been previously described at the global scale with a more limited set of traits (adult plant height, stem-specific density, leaf area, leaf mass per leaf area, leaf $\mathrm{N}$ and diaspore mass) (Díaz et al. 2016) or for cerrado plant communities 


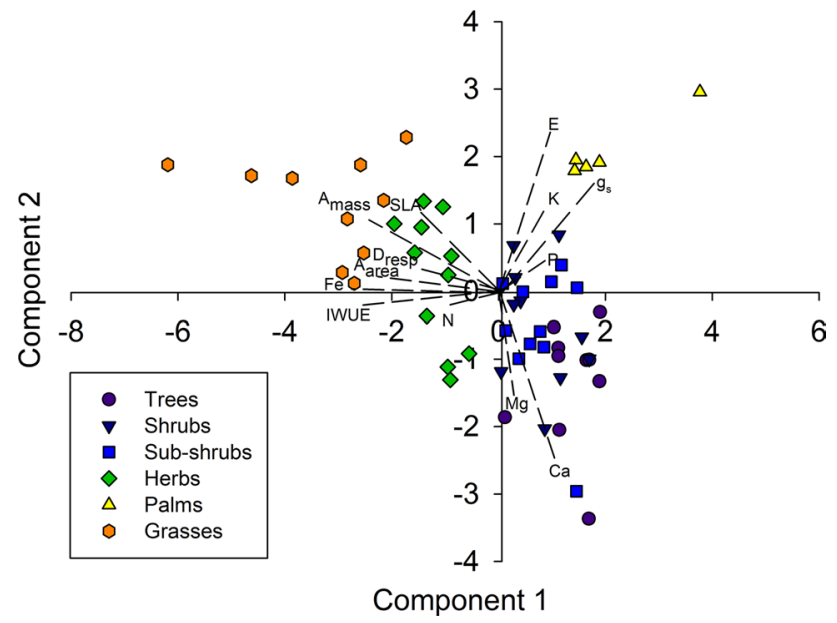

Fig. 4 Species of distinct growth forms projected on the plane defined by principal component axes 1 and 2. Dashed lines indicate weighing of vectors representing the 13 leaf traits considered. $A_{\text {area }}$ maximum $\mathrm{CO}_{2}$ assimilation on a leaf area basis, $g_{s}$ stomatal conductance at $A_{\text {area }}$, E leaf transpiration, $D_{\text {resp }}$ leaf respiration under dark conditions, $S L A$ specific leaf area, $A_{\text {mass }}$ maximum $\mathrm{CO}_{2}$ assimilation on a leaf mass basis, IWUE intrinsic water use efficiency, $N$ leaf nitrogen concentration, $P$ leaf phosphorous concentration, $\mathrm{Ca}$ leaf calcium concentration, $M g$ leaf magnesium concentration, $K$ leaf potassium concentration, $\mathrm{Fe}$ leaf iron concentration

at a local scale based on traits related to plant regeneration, reproduction and dispersal (Silva and Batalha 2011). Studies that have specifically focused on leaf traits have generally explored bivariate scaling relationships influencing specific physiological and mechanical functions of leaves (e.g., Wright et al. 2005; Niklas et al. 2007). Here we took much broader approach, by including not only a much larger number of traits that better represent leaf functional typologies but also by sampling a large diversity of growth forms. In this way, we were able to relate leaf functional typologies to specific plant morphologies and, therefore, provide strong evidence of coordinated evolution of structure and function of the whole plant.

The great diversity of plant growth forms is frequently overlooked in functional studies of plant communities, especially in savannas, where studies focused mostly on grasses and trees, the dominant growth forms in many African and Australian savannas (Prior et al. 2004; Goldstein et al. 2008; Cianciaruso et al. 2013). Functional groups have been used as an important tool to simplify the description of patterns and processes in community assembly and function (Pla et al. 2012). Because our results show that species with similar external plant morphology also share similar values for a large range of leaf traits, we can also effectively represent plant community structure and function in diverse savannas by assembling the species into plant morphological groups (growth forms).
There is an ongoing debate on the role of abiotic and biotic interactions on the assembling of cerrado plant communities (Silva et al. 2010). Studies using functional traits have shown that functional similarity does not limit the co-occurrence of species (Silva and Batalha 2009; Silva et al. 2010), which suggests that the assembling of plant species in typical cerrado communities would be mainly dependent on the role of environmental filters (especially fire frequency, rainfall seasonality and nutrient-poor soils) (Silva et al. 2010). The much higher number of herbs and grasses, as opposed to large woody species in Brazilian savannas (around 7.1:1, Mendonça et al. 2008), suggests that plants in this type of environment have been subjected to selection pressures favoring shorter growth forms (Veldman et al. 2015). Taken this into account, fire may be the strongest selective factor favoring divergence in plant functional traits related to the patterns of resource acquisition and use, as predicted for disturbance-prone environments (Grime 2006). Frequent fires would constrain strategies that would require that a plant reaches a relatively large size for successful reproduction, because the stem would be repeatedly destroyed (Hoffmann et al. 2012). Species with traits allowing rapid shoot growth or accumulation of reserves that could be rapidly remobilized for plant growth and reproduction following a fire event would be favored, which would be the case in most cerrado herbs, grasses and sub-shrubs (Appezzato-da-Glória et al. 2008; Almeida et al. 2015, De Moraes et al. 2016). This reasoning is further supported by the higher values of SLA (Fig. 2) of those growth forms (grasses, herbs and sub-shrubs). SLA is a key trait because it is recognized to be positively correlated with the rates of resource extraction (Wilson et al. 1999; Reich et al. 2003) and growth (Evans and Poorter 2001; Shipley 2002; Rossatto et al. 2009).

Despite grasses being the growth form with the lowest leaf macronutrient concentrations (Fig. 4), they had the highest rates of $\mathrm{CO}_{2}$ assimilation on an area and mass basis, which is consistent with their high dominance in terms of species, biomass and productivity in tropical savannas (Sankaran et al. 2004). The high photosynthetic rates are explained by the fact that the majority of the studied grasses were $\mathrm{C}_{4}$ (see Table S2), possessing mechanisms for increasing the $\mathrm{CO}_{2}$ concentration in the bundle sheath cells (Schmitt and Edwards 1981). Herbs would be subjected to strong competition with grasses for aboveground space occupancy in the savanna understory (Del-Val and Crawley 2005). Because of their higher leaf nutrient requirements, herbs would not be able to rapidly achieve the high shoot biomass that would allow them to outcompete grasses. Their low values of IWUE in comparison to grasses would also make herbs more dependent on the periods of high moisture availability in the soil and suggest an earlier onset of dormancy as the soil starts drying during the dry season. 
Investment in bud-bearing underground storage organs and the catabolism of existing reserves rather than current photosynthates as the main driver for growth and reproduction would be crucial for perennial herbs (De Moraes et al. 2016). Although further studies are necessary, we also suggest that small differences in the timing of resprouting and in shade tolerance may play a significant role in minimizing the effects of aboveground competition with grasses in this regard.

Much has been proposed about the coexistence of grasses and trees in savanna systems in the context of resource exploitation and competition, especially for water and nutrients (Walter 1971; Sankaran et al. 2004, 2005). Our results reinforce the idea that not only grasses and trees, but herbs as well have different leaf nutrient requirements that might enable them to exploit different soil resource-based niches (for instance, exploring different soil depths; Higgins et al. 2000; February and Higgins 2010). We recently showed that patterns of soil water uptake differ drastically between trees, herbs and grasses coexisting in the same savanna site (Rossatto et al. 2013b, 2014), so water and nutrient uptake may occur in different zones of the soil profile, providing the required nutrients for each growth form without strong belowground competition for these resources. On an individual basis, a tree has more leaves than a small plant, and would require a greater amount of nutrients when considering total biomass (Ludwig et al. 2001). The exploitation of different soil niches and different nutrient requirements for optimal leaf function could be crucial for coexistence.

In comparison to the other growth forms, individual leaf traits of palms showed contrasting patterns depending on which trait was examined. In some cases, trait values were similar to those of trees (as for SLA, $D_{\text {resp }}$ and $A_{\text {mass }}$ ); however, distinct from woody and herbaceous species, palms showed the highest values of $g_{\mathrm{s}}$ and the lowest values of IWUE. The clear separation of palms from trees and shrubs along the second axis of the PCA ordination strongly suggests that palms have a distinct syndrome of leaf traits, which are perhaps the result of phylogenetic inertia (Shanahan 2011) and their exclusive growth form. Palms have their origin in the Cretaceous ca $100 \mathrm{~m}$ y or more ago in humid tropical regions (Couvreur et al. 2011) and are commonly encountered in tropical vegetation, especially in savanna landscapes (Lima et al. 2003). Cerrado palms are characterized by the presence of erect underground stems and a relatively deep root system and may take several years to flower (Rawitscher and Rachid 1946; Rawitscher 1948). They are also reported to be fire resistant due to the absence of a peripheral cambium whereas the single meristem is covered by thermally insulating leaf bases at the stipe apex. Although additional studies are required, such a distinct set of traits suggests different patterns of resource acquisition and water use strategies, which are probably associated with their unique vasculature and large water storage capacity (Tomlinson 2006) while the apparent inability of palms to undergo dormant periods (Tomlinson 2006) might make the deep-rooted habit essential in seasonal tropical environments, such as savannas. Overall, these features may contribute to alleviate resource competition with trees and shrubs, which are the major dominant woody growth forms on the savanna environment (Barot et al. 2000). Furthermore, it would also allow the maintenance of high rates of transpiration (high $g_{\mathrm{s}}$ ), which might explain the high concentrations of $\mathrm{K}$ in the leaf tissues of those species.

IPCC predictions of higher air temperatures, increasing $\mathrm{CO}_{2}$ levels, more frequent fires and more intense droughts (IPCC 2013) would be beneficial for the smaller $C_{3}$ growth forms, i.e. herbs and sub-shrubs. Positive growth responses of $\mathrm{C}_{3}$ species to $\mathrm{CO}_{2}$ enrichment are better characterized when nutrients are non-limiting (e.g., Dijkstra et al. 2002); which is not the case of the cerrado of Central Brazil. Most of the cerrado occur on highly leached soils depleted of nutrients, particularly $\mathrm{Ca}$ and $\mathrm{P}$ (Haridasan 2008). The relative high nutrient requirement of herbs and sub-shrubs leaves (particularly $\mathrm{Ca}$ and $\mathrm{Mg}$ ) suggests that any increases in carbon gain would probably be diverted to underground storage which would make these growth forms more resilient to long periods of droughts or more frequent dry season fires, but larger increases in biomass relative to grasses are not expected. On the other hand, several reports have suggested that increasing $\mathrm{CO}_{2}$ levels have resulted in increases in canopy cover of the woody layer and in encroachment of the woody vegetation in grasslands and in open types of savannas (Stevens et al. 2016). However, the observed increase in wood layer cover and biomass in savannas has only occurred in fireprotected areas and significantly impacted the richness and diversity of herbs, sub-shrubs and shrubs (Pinheiro et al. 2016).

In conclusion, we provide strong evidence that the use of growth forms as functional groups is an efficient and convenient way of simplifying plant diversity in savanna systems. At the leaf level, shrubs and trees, herbs, grasses and palms have unique nutrient requirements for optimal leaf function and converged to different combination of trait values within the multivariate trait space, which suggests major trends of specialization in terms or resource use and conservation. Sub-shrubs are unique in the sense that they have a leaf anatomy similar to herbs (Rossatto et al. 2015) but are functionally clustered with trees and shrubs, which suggests that even though they are on an evolutionary trajectory that converges ecologically with herbaceous plants, they are not phylogenetically independent of the tree lineages from which they evolved. 
Acknowledgements We thank Reserva Ecológica do IBGE, Brasília, DF-Brazil, for logistic support. The Brazilian National Council of Research (CNPq) (Grant Nos. 141624/2009-4, 484545/2012-4, 303637/2011-0 and 301589/2015-1), the C.T. de Wit Graduate School for Production Ecology \& Resource Conservation, Wageningen University (082PE\&RC2016) and BIOTA FAPESP (2013/18049-6).

Author contribution statement DRR and ACF conceived and designed the study. DRR collected the data and performed the statistical analysis. DRR and ACF wrote the manuscript.

\section{References}

Ackerly D (2009) Conservatism and diversification of plant functional traits: evolutionary rates versus phylogenetic signal. PNAS 106(Supplement 2):19699-19706

Allen SW, Grimshaw HM, Parkinson JA, Quarmby C (1974) Chemical analysis of ecological materials. Blackwell Scientific Publications, Oxford

Almeida VO, Carneiro RV, Carvalho MAM, Figueiredo-Ribeiro RCL, Moraes MG (2015) Diversity of non-structural carbohydrates in the underground organs of five Iridaceae species from the Cerrado (Brazil). South Afr J Bot 96:105-111

Appezzato-da-Glória BG, Cury MK, Soares M, Rocha R, Hayashi HA (2008) Underground systems of Asteraceae species from the Brazilian Cerrado. J Torrey Bot Soc 135:103-113

Barot S, Gignoux J, Vuattoux R, Legendre S (2000) Demography of a savanna palm tree in Ivory Coast (Lamto): population persistence and life-history. J Trop Ecol 16:637-655

Cavender-Bares J, Ackerly DD, Baum DA, Bazzaz FA (2004) Phylogenetic overdispersion in Floridian oak communities. Am Nat 163(6):823-843

Cianciaruso MV, Silva IA, Manica LT, Souza JP (2013) Leaf habit does not predict leaf functional traits in cerrado woody species. Basic Appl Ecol 14:404-412

Couvreur TLP, Forest F, Baker WJ (2011) Diversification of palms in the earliest tropical rain forests. Biosystematics 21-27 February Berlin 2011. Botanic Gardens and Botanical Museum, BerlinDahlem, Freie Universität Berlin, Berlin, pp 86-87

Dansereau P (1951) Description and recording of vegetation upon a structural basis. Ecol 32(2):172-229

De Moraes MG, Carvalho MAM, Franco AC, Pollock CJ, FigueiredoRibeiro RCN (2016) Fire and drought: soluble carbohydrate storage and survival mechanisms in herbaceous plants from the cerrado. BioScience 66:107-117

Del-Val EK, Crawley MJ (2005) What limits herb biomass in grasslands: competition or herbivory? Oecologia 142(2):202-211

Diaz S, Hodgson JG, Thompson K, Cabido M, Cornelissen JHC, Jalili A et al (2004) The plant traits that drive ecosystems: evidence from three continents. J Veg Sci 15(3):295-304

Díaz S, Kattge J, Cornelissen JH, Wright IJ, Lavorel S, Dray S et al (2016) The global spectrum of plant form and function. Nature 529(7585):167-171

Dijkstra P, Hymus G, Colavito D, Vieglais DA, Cundari CM, Johnson DP, Hungate BA, Hinkle CR, Drake BG (2002) Elevated atmospheric $\mathrm{CO}_{2}$ stimulates aboveground biomass in a fire-regenerated scrub-oak ecosystem. Glob Change Biol 8:90-103

Edwards EJ, Smith SA (2010) Phylogenetic analyses reveal the shady history of $\mathrm{C}_{4}$ grasses. Proc Natl Acad Sci 107:2532-2537

Evans J, Poorter H (2001) Photosynthetic acclimation of plants to growth irradiance: the relative importance of specific leaf area and nitrogen partitioning in maximizing carbon gain. Plant Cell Environ 24(8):755-767
February EC, Higgins SI (2010) The distribution of tree and grass roots in savannas in relation to soil nitrogen and water. S Afr J Bot 76(3):517-523

Franco AC (2002) Ecophysiology of woody plants. In: Oliveira PS, Marquis RJ (eds) The cerrados of Brazil. Columbia University Press, New York, pp 178-197

Franco AC, Bustamante M, Caldas LS, Goldstein G, Meinzer FC, Kozovits AR, Rundel P, Coradin VTR (2005) Leaf functional traits of Neotropical savanna trees in relation to seasonal water deficit. Trees 19:326-335

Franco AC, Rossatto DR, Silva LDCR, Ferreira CS (2014) Cerrado vegetation and global change: the role of functional types, resource availability and disturbance in regulating plant community responses to rising $\mathrm{CO}_{2}$ levels and climate warming. Exp Plant Phys 26(1):19-38

Fukami T, Martijn Bezemer T, Mortimer SR, Putten WH (2005) Species divergence and trait convergence in experimental plant community assembly. Ecol Lett 8(12):1283-1290

Garnier E, Navas ML (2012) A trait-based approach to comparative functional plant ecology: concepts, methods and applications for agroecology. A review. Agron Sustain Dev 32(2):365-399

Goldstein G, Meinzer FC, Bucci SJ, Scholz FG, Franco AC, Hoffmann WA (2008) Water economy of neotropical savanna trees: six paradigms revisited. Tree Phys 28(3):395-404

Gotelli NJ, Ellison AM (2004) A primer of ecological statistics. Sinauer Associates, Massachusetts

Gottsberger G, Silberbauer-Gottsberger I (2006) Life in the cerrado: a South American tropical seasonal ecosystem. Vol I, Origin, structure, dynamics and plant use. Reta Verlag, Ulm

Grime JP (2002) Declining plant diversity: empty niches or functional shifts? J Veg Sci 13:457-460

Grime JP (2006) Trait convergence and trait divergence in herbaceous plant communities: mechanisms and consequences. J Veg Scie 17(2):255-260

Hammer $\varnothing$, Harper DAT, Ryan PD (2001) PAST-PAlaeontological STatistics, ver. 1.89. Palaeontologia electronica 4(1):1-9

Haridasan M (2000) Nutrição mineral das plantas natives do cerrado. Rev Bras Fis Veg 12:54-64

Haridasan M (2008) Nutritional adaptations of native plants of the cerrado biome in acid soils. Braz J Plant Phys 20(3):183-195

Higgins SI, Bond WJ, Trollope WS (2000) Fire, resprouting and variability: a recipe for grass-tree coexistence in savanna. $\mathrm{J}$ Ecol 88(2):213-229

Hoffmann WA (1996) The effects of cover and fire on seedling establishment in a neotropical savanna. J Ecol 84:383-393

Hoffmann WA, Geiger EL, Gotsch S, Rossatto DR, Silva LCR, Lau OL, Haridasan M, Franco AC (2012) Ecological thresholds at the savanna-forest boundary: how plant traits, resources and fire govern the distribution of tropical biomes. Ecol Lett $15: 759-768$

IPCC (2013) Working group I contribution to the IPCC fifth assessment report climate change 2013: the physical science basis. http://www.climatechange2013.org. Accessed 24 Oct 2016

Lavorel S, Garnier E (2002) Predicting changes in community composition and ecosystem functioning from plant traits: revisiting the Holy Grail. Funct Ecol 16(5):545-556

Lima ES, Felfili JM, Marimon BS, Scariot A (2003) Diversidade, estrutura e distribuição espacial de palmeiras em um cerrado sensu stricto no Brasil Central-DF. Ver Bras Bot 26(3):361-370

Liu H, Edwards EJ, Freckleton RP, Osborne CP (2012) Phylogenetic niche conservatism in $\mathrm{C}_{4}$ grasses. Oecologia 170(3):835-845

Lortie CJ, Brooker RW, Choler P, Kikvidze Z, Michalet R, Pugnaire FI, Callaway RM (2004) Rethinking plant community theory. Oikos 107(2):433-438 
Ludwig F, Kroon H, Prins HH, Berendse F (2001) Effects of nutrients and shade on tree-grass interactions in an East African savanna. $J$ Veg Scien 12(4):579-588

Maurin O, Davies TJ, Burrows JE, Daru BH, Yessoufou K, Muasya AM, van der Bank M, Bond WJ (2014) Savanna fire and the origins of the 'underground forests' of Africa. New Phytol 204(1):201-214

Mendonça RC, Felfili JM, Walter BMT, Silva-Júnior MC, Rezende AB, Filgueiras TS, Nogueira PE, Fagg CW (2008) Flora Vascular do Bioma Cerrado: checklist com 12.356 espécies. In: Sano SM, Almeida SP, Ribeiro JF (eds) Cerrado: Ecologia e Flora, vol 2. Embrapa Cerrados, Brasília, pp 213-228

Niklas KJ, Cobb ED, Niinemets U, Reich PB, Sellin A, Shipley B, Wright IJ (2007) "Diminishing returns" in the scaling of functional leaf traits across and within species groups. PNAS 104:8891-8896

Oliveira-Filho AT, Ratter JA (2002) Vegetation physiognomies and woody flora of the Cerrado Biome. In: Oliveira PS, Marquis RJ (eds) The cerrados of Brazil: ecology and natural history of a Neotropical savannaColumbia University Press, New York

Pinheiro LFS, Kolb R, Rossatto D (2016) Changes in irradiance and soil properties explain why typical non-arboreal savanna species disappear under tree encroachment. Austr J Bot 64(4):333-341

Pla L, Casanoves F, Di Rienzo J (2012) Quantifying functional biodiversity. Springer, San Bernardino, CA, USA, p 98

Prior LD, Bowman DMJS, Eamus D (2004) Seasonal differences in leaf attributes in Australian tropical tree species: family and habitat comparisons. Funct Ecol 18:707-718

Rawitscher F (1948) The water economy of the vegetation of the 'Campos Cerrados' in southern Brazil. J Ecol 36:237-268

Rawitscher FK, Rachid M (1946) Troncos subterrâneos de plantas brasileiras. Ann Acad Bras Ciencias 18:261-280

Reich PB, Wright J, Cavender-Bares J, Craine JM, Oleksyn J, Westoby M, Walters MB (2003) The evolution of plant functional variation: traits, spectra, and strategies. Int J Plant Sci 164(3 Suppl.):143-164

Roncal J, Henderson A, Borchsenius F, Cardoso SRS, Balslev $\mathrm{H}$ (2012) Can phylogenetic signal, character displacement, or random phenotypic drift explain the morphological variation in the genus Geonoma (Arecaceae)? Biol J Linn Soc 106(3):528-539

Rossatto DR (2014) Spatial patterns of species richness and phylogenetic diversity of woody plants in the neotropical savannas of Brazil. Braz J Bot 37(3):283-292

Rossatto DR, Hoffmann WA, Franco AC (2009) Differences in growth patterns between co-occurring forest and savanna trees affect the forest-savanna boundary. Funct Ecol 23:689-698

Rossatto DR, Silva LCR, Villalobos-Veja R, Sternberg LSL, Franco AC (2012) Depth of water uptake in woody plants relates to groundwater level and vegetation structure along a topographic gradient in a neotropical savanna. Environ Exp Bot 77:259-266

Rossatto DR, Hoffmann WA, Silva LCR, Haridasan M, Sternberg LSL, Franco AC (2013a) Seasonal variation in leaf traits between congeneric savanna and forest trees in Central Brazil: implications for forest expansion into savanna. Trees 27:1139-1150

Rossatto DR, Sternberg LSL, Franco AC (2013b) The partitioning of water uptake between growth forms in a neotropical savanna: do herbs exploit a third water source niche? Plant Biol 15:84-92

Rossatto DR, Silva LCR, Sternberg LSL, Franco AC (2014) Do woody and herbaceous species compete for soil water across topographic gradients? Evidence for niche partitioning in a neotropical savanna. S Afr J Bot 91:14-18

Rossatto DR, Kolb RM, Franco AC (2015) Leaf anatomy is associated with the type of growth form in neotropical savanna plants. Bot 93(8):507-518

Rowe N, Speck T (2005) Plant growth forms: an ecological and evolutionary perspective. New Phytol 166(1):61-72
Sandel B, Monnet AC, Vorontsova M (2016) Multidimensional structure of grass functional traits among species and assemblages. J Veg Sci 27(5):1047-1060

Sankaran M, Ratnam J, Hanan NP (2004) Tree-grass coexistence in savannas revisited-insights from an examination of assumptions and mechanisms invoked in existing models. Ecol Lett 7(6):480-490

Sankaran M, Hanan NP, Scholes RJ, Ratnam J, Augustine DJ, Cade BS, Gignoux J, Higgins S, Roux X, Ludwig F, Ardo J, Banyikwa F, Bronn A, Bucini G, Caylor KK, Coughenour MB, Diouf A, Ekaya W, Feral CJ, February EC, Frost PG, Hiernaux P, Hrabar H, Metzger KL, Prins HHT, Ringrose S, Sea W, Tews J, Worden J, Zambatis N (2005) Determinants of woody cover in African savannas. Nature 438:846-849

Santiago LS, Wright SJ (2007) Leaf functional traits of tropical forest plants in relation to growth form. Funct Ecol 21:19-27

Schmitt MR, Edwards GE (1981) Photosynthetic capacity and nitrogen use efficiency of maize, wheat, and rice: a comparison between $\mathrm{C}_{3}$ and $\mathrm{C}_{4}$ photosynthesis. J Exp Bot 32(3):459-466

Shanahan T (2011) Phylogenetic inertia and Darwin's higher law. Stud Hist Philos Sci Part C Stud Hist Philos Biol Biomed Sci 42(1):60-68

Shipley B (2002) Trade-offs between net assimilation rate and specific leaf area in determining relative growth rate: relationship with daily irradiance. Funct Ecol 16:682-689

Silva IA, Batalha MA (2009) Co-occurrence of tree species at fine spatial scale in a woodland cerrado, southeastern Brazil. Plant Ecol 200(2):277-286

Silva IA, Batalha MA (2011) Plant functional types in Brazilian savannas: the niche partitioning between herbaceous and woody species. Perspect Plant Ecol Evol Syst 13:201-206

Silva I, Carvalho G, Loiola P, Cianciaruso M, Batalha M (2010) Herbaceous and shrubby species co-occurrences in Brazilian savannas: the roles of fire and chance. Community Ecol 11(1):97-104

Simon MF, Grether R, de Queiroz LP, Särkinen TE, Dutra VF, Hughes CE (2011) The evolutionary history of Mimosa (Leguminosae): toward a phylogeny of the sensitive plants. Am J Bot 98(7):1201-1221

Stevens N, Lehmann CE, Murphy BP, Durigan G (2016) Savanna woody encroachment is widespread across three continents. Glob Change Biol. doi:10.1111/gcb.13409 (in press)

THE Angiosperm PHYLOGENY GROUP (2016) An update of the Angiosperm Phylogeny Group classification for the orders and families of flowering plants: APG IV. Bot J Linn Soc 181:1-20

Tomlinson PB (2006) The uniqueness of palms. Bot J Linn Soc 151:5-14

Veldman JW, Buisson E, Durigan G, Fernandes GW, Le Stradic S, Mahy G, Negreiros D, Overbeck GE, Veldman RG, Zaloumis NP, Puts FE, Bond WJ (2015) Toward an old-growth concept for grasslands, savannas and woodlands. Front Ecol Environ 13(3):154-162

Walter H (1971) Natural savannas. Ecology of tropical and subtropical vegetation. Oliver and Boyd, Edinburgh

Webb CO, Ackerly DD, McPeek MA, Donoghue MJ (2002) Phylogenies and community ecology. Ann Rev Ecol Syst 33:475-505

Westoby M, Falster DS, Moles AT, Vesk PA, Wright IJ (2002) Plant ecological strategies: some leading dimensions of variation between species. Annu Rev Ecol Syst 33:125-159

Wilson PJ, Thompson KEN, Hodgson JG (1999) Specific leaf area and leaf dry matter content as alternative predictors of plant strategies. New Phytol 143(1):155-162

Wright IJ, Reich PB, Cornelissen JHC et al (2005) Assessing the generality of global leaf trait relationships. New Phytol 166:485-496 